\title{
Mikko Kallionsivu
}

\section{Menneisyys uudella tapaa? Kulttuuripoetiikka ja uushistorismi}

Stephen Greenblattin uusin teos, poleemisesti modernisaatiota ja renessanssihenkeä käsittelevä The Swerve. How the World Became Modern (2011) sai Yhdysvalloissa aikaan vilkkaan keskustelun tai oikeastaan väittelyn konservatiivisten ja vapaamielisten kulttuuripiirien kesken. Tämä tietokirjallisuuden bestseller-teos käsittelee uuden ihmis- ja maailmankuvan esiinmarssia atomiopin, positiivisen mielihyvän, historian märäytymättömyyden ja vapaan tahdon näkökulmasta. Greenblatt kartoittaa näiden ideoiden ja niihin liittyvien ajatusmallien leviämistä ja toisaalta niihin kohdistunutta sensuuria ja itsesensuuria.

The Swerve sai myös huomattavia palkintoja (vuoden 2012 Pulitzer-palkinto, vuoden 2011 National Book Award -palkinto). Tämä siis huolimatta teoksen selkeistä, keskiaikaa koskevista historiantutkimuksellisista puutteista - joiden olemassaolon kirjoittaja on sittemmin myöntänytkin. Saadakseen korostamansa renessanssihengen piirteet selkeästi näkyviin on Greenblatt samalla luonut keskiajasta karikatyyrinomaisen kuvan. Kulttuuripoeetikon käsittelyssä monet renessanssia edeltäneistä ääri-ilmiöistä - kuten vaikkapa varsin marginaalinen flagellanttiliike - asettuvat edustamaan laajempaa kokonaisuutta. Myös keskiajan intellektuaalinen elämä sivuutetaan lähes täysin, muutamaa radikaalia ajattelijaa lukuun ottamatta. Miksi osittain epäonnistunut tai ainakin valitettavan epätarkka teos sitten myi niin hyvin?

Kuten teoksen The Swerve suosio ja toisaalta sen kohtaama myrskyisä kritiikki osaltaan osoittaa, kulttuuripoetiikka jaksaa puhuttaa suhteellisesta iäkkyydestään huolimatta. 1990-luvulla asemansa vakiinnuttanut tutkimussuuntaus on tavallaan jo menneisyyttä nopeasti vaihtuvien trendien luonnehtimalla kirjallisuudentutkimuksen nykykentällä. Ainakin se on tutkimussuuntauksena institutionalisoitunut - seikka, jossa on alkuperäisen radikaalin, kantaaottavan tutkimuseetoksen kannalta tarkasteltuna aimo annos ironiaa.

Esittelen tässä puheenvuorossa yleisesti kulttuuripoetiikkaa (cultural poetics) ja uushistorismia (new historicism) kirjallisuudentutkimuksellisena, erityisesti kirjallisuushistoriallisena metodina. Lähestymistapa on itselleni tuttu, sillä olen vastikään julkaissut kulttuuripoeettisen yleisen kirjallisuustieteen tohtorinväitöskirjan (Kallionsivu 2013). Tässä hahmottelen lähestymistavan erityisluonnetta nimenomaan sen puhuttelevuuden näkökulmasta. 


\section{Kulttuuripoetiikan lähtökohdat ja harjoittajia}

Kulttuuripoetiikka on leimallisesti yhdysvaltalaista kirjallisuuden, kulttuurin ja historian tutkimusta. Sisarsuuntaus, marxilaisesta teoriasta voimakkaammin ponnistava kulttuurimaterialismi (cultural materialism), on pääosin brittiläinen ilmiö. Uushistorismia voi käyttää kummankin suuntauksen kattokäsitteenä, mutta tarkalleen ottaen sillä viitataan Yhdysvaltojen suuntaan.

Kulttuuripoetiikka muodostuu pitkin matkaa tarkentuneista pohjaoletuksista ja yhteisesti jaetuista kiinnostuksen kohteista - ei niinkään valmiista metodisesta kehikosta. Esitystavaltaan se on hyvin vapaa. Nojatessaan postmoderniin ajatteluun kulttuuripoeetikot tulevat usein vannoneeksi metodikriittisyyden ja näennäisen teoriakielteisyyden nimiin. Tämä näkyy selkeästi myös heidän tavassaan tuottaa käytännön tutkimusta. Koska mikään valmis malli ei voi tyhjentävästi selittää tai vangita inhimillisen todellisuuden loputonta moninaisuutta ja muutosta - Greenblattin edellä mainitun teoksen nimeä mukaillen, maailman väistämätöntä "heittelehtimistä" - on teoria häivytetty pääsääntöisesti taustalle. Painotuksistaan huolimatta kulttuuripoeetikot kuitenkin lankeavat toisinaan kuvailemaan analyyttisesti omaa työtään. Tätä kautta kuva suuntauksen esikuvista ja perusperiaatteista on melko tarkasti haarukoitavissa.

Kulttuuripoeetikkojen keskeisten esikuvien ajatuksista on luotu omalaatuinen, innovatiivinen synteesi. Erityisesti on mainittava Michel Foucault, Hayden White ja Hans-Georg Gadamer. Myös Mihail Bahtin ja Raymond Williams kummittelevat taustalla. Suuntauksen keskeisin oma teoreetikko on englantilaista renessanssiteatteria, länsimaisten identiteettien modernisaatiota ja erityisesti Shakespearea tutkiva Greenblatt. Muita mainitsemisen arvoisia kulttuuripoeetikkoja ovat vaikkapa 1700- ja 1800-lukujen brittikirjallisuutta tutkiva Catherine Gallagher sekä brittiläisestä romantiikasta ja sitä uudemmasta kirjallisuudesta kiinnostunut kirjallisuudentutkija Jerome McGann. Kulttuuripoeetikoille tyypillisesti nämä tutkijat ulottavat mielenkiintonsa kirjallisuushistorian ohella vahvasti myös tutkimiensa aikakausien kulttuurihistoriaan, valta-asetelmiin ja sosiaalisiin suhteisiin. Suuntauksen kärkinimet ja eetos assosioidaan voimakkaasti Berkeleyn yliopistoon Kaliforniassa.

Monet lähestymistavan pioneereista oli koulutettu toimimaan tekstilähtöisesti. Aluksi kyseessä olikin paljolti uuskritiikin vastaliike; kirjallisuutta haluttiin tutkia entistä vapaammin ja laveammin. Stanley Fish nimesi lähestymistavan pioneerit aikoinaan epiteetillä "the young and the restless", nuoret ja levottomat. Sittemmin kulttuuripoetiikka on vakiinnuttanut asemansa yhdysvaltalaisessa akateemisessa kulttuurissa, ja mainittu "rauhattomuus" onkin yleistynyt laajemminkin kirjallisuudentutkimusta määrittäväksi piirteeksi - eikä monia lähestymistavan kärkinimistä voi sitä paitsi kutsua nuoriksi enää edes akateemisella mittapuulla. Edelleen, koska kulttuuripoetiikka on jo suhteellisen vanha tutkimussuuntaus, on osa sen suosituimmista teksteistä muuttunut itsessäänkin 
jo klassikoiksi. Tällainen on esimerkiksi Greenblattin varhaismodernien identiteettien muotoutumista kirjallisuuden näkökulmasta tutkiva Renaissance Self-Fashioning. From More to Shakespeare (1980).

Kulttuuripoetiikan lippulaiva on vuonna 1983 perustettu poikkitieteellinen, kirjallisuuden, historian ja kulttuurin ilmiöitä tarkasteleva Representations-lehti (http://www.representations.org/). Lehden artikkelit tarjoavat hyvän poikkileikkauksen lähestymissuunnan keskeisistä painotuksista ja tutkimusmenetelmistä - jotka sinällään ovat toki varsin kirjavia. Representations edustaa kulttuuripoetiikkaa sen paraatimuodossa: vaikka kulttuuripoeettinen ote soveltuu myös monografioiden tuottamiseen, se on parhaimmillaan lyhyiden ja iskevien artikkelien yhteydessä. Tämä siksi, että pidemmistä käsittelyistä usein puuttuva ajatuksen lennokkuus pääsee niissä oikeuksiinsa.

\section{Kulttuuripoeettinen metodi}

Keskeisiä kulttuuripoetiikan opinkappaleita ovat historiallinen relativismi, minuus sosiaalisena konstruktiona sekä tekstien asema historian tuotteina ja tuottajina. Kulttuuripoetiikka pyrkii tarkastelemaan menneisyyden kaunokirjallisia tekstejä nimensä mukaisesti siten, että ne nähdään kiinteänä osana oman aikakautensa tekstuaalista kokonaismaailmaa - osana kulttuurin "poeettista", muuttuvaa kokonaiskuvaa ja -rakennetta. Erityistä huomiota kiinnitetään vallan ja talouden teksteihin. Näistä ja tutkittavasta fiktiosta pyritään löytämään jälkiä menneisyyden yhteiskunnallisista valtasuhteista sekä identiteettien muotoutumisesta.

Toistuva, leimallinen tyylipiirre kulttuuripoetiikassa on siis se, että valittuja kirjallisia tekstejä tarkastellaan saman aikakauden ei-kirjallisten tekstien kanssa. Kuten mitkä tahansa tekstit ja kommunikaatio ylipäätäänkin, ovat myös kaunokirjalliset tekstit ennen kaikkea yhteydenottoja (tai yhteenottoja) laajan ja monipuolisen inhimillisen todellisuuden kanssa. Tämä symbolinen todellisuus koostuu erilaisista ja jopa toisilleen vastakohtaisista uskomuksista ja näkemyksistä, arvoista, mieltymyksistä, puolueellisuuksista, ennakkoluuloista, kriiseistä ja ratkaisemattomista paradokseista. Lisäksi se koostuu myös symbolisista, taloudellisista ja materiaalisista investoinneista ja riskinottotilanteista.

Tätä virtaavaa, yksilön ja yhteisön välistä sosiokulttuurista vaihtotasejärjestelmää vasten valitut tekstit on ymmärrettävä eräänlaisina todellisuuden vapaina ja oivaltavina tulkintoina. Kirjailija on samanaikaisesti sekä taiteen kyyninen kauppamies että inhimillisen todellisuuden herkkä havainnoitsija. Hän tarttuu hanakasti virtaaviin, aikakaudelleen ominaisiin symboleihin, aikansa ymmärrykseen ja tietämisen tapoihin. Anastamaansa materiaalia luovasti tulkiten ja vapaasti hyväksikäyttäen hän markkinoi omia näkemyksiään, omaa myyväksi hiottua esteettistä agendaansa - ja itseäänkin taiteentekijän ominaisuudessa. Autenttisuus onkin ymmärrettävä tässä yhteydessä 
enemmän yhteisöllisenä kuin yksilöllisenä piirteenä. Menestyneet teokset ovat aina sekä todistajanlausuntoja tietyn sosiaalisen todellisuuden luonteesta, että myös tämän kompleksisen todellisuuden läpeensä muotoilemia. Niiden puhuttelevuus ja suosio perustuvat omassa aikalaiskontekstissaan nimenomaan siihen, että ne tavoittavat jotakin olennaista omasta ajastaan, omille aikalaisilleen. Siksi ne sisältävät arvokasta tietoa myös ei-kaunokirjallisten, ei-esteettisten tiedonintressien näkökulmasta.

\section{Menneisyys ja nykyisyys}

Vaikka menneisyyden tekstit sisältävätkin siis arvokkaita jälkiä jostakin nyt jo kadonneesta, suoraa paluuta menneisyyteen ei ole. Kulttuuripoeetikkojen mukaan vastaanoton historiallista kerrostuneisuutta ei voida jälkikäteen purkaa. Menneisyyden, nykyisyyden ja tulevaisuuden muodostamaa yhtälöä on tarkasteltava kokonaisuutena. Kulttuuripoetiikka ei koskaan tarkastele menneisyyttä ja kanonisoituja teoksia "sinällään”. Moinen toimenpide nähdään mahdottomaksi. Merkitykset ovat aina osa kulttuureille ominaiseksi nähtyä - ja siten myös kulttuuripoeetikkojen teksteille ominaista - päättymätöntä ja tyhjentymätöntä merkityksenantoprosessia. Historialliset totuudet eivät siis ole pysyviä, vaan menneisyyttä tulkitaan aina vahvasti nykyisyyden tarpeisiin. Kulttuuripoeettinen perinne ei toki ole itsekään tästä korostamastaan säännöstä poikkeus, vaan sen harjoittajat myöntävät avoimesti oman agendansa. Historian muodot ja paineet ilmenevät juuri meidän henkilökohtaisissa ajattelu- ja toimintatavoissamme, uskomuksissamme ja mielihaluissamme. Mikä tärkeintä, kuvamme menneisyydestä määrittyy paljolti menneisyyden fiktion kautta. Oikein analysoituna tämä fiktio tarjoaa yhdenlaisen, merkittävän pääsyn menneisyyden ja menneisyyden identiteettien pariin (nykyhetken näkökulmasta) - samoin kuin omaan historialliseen olemassaoloomme (nykyhetken näkökulmasta). Koska merkitysten nähdään kiertävän loputtomasti tulkinnan ja uudelleentulkinnan hermeneuttisessa kehässä, ei liene yllättävää, että kaikenlaiset essentialistisilta haiskahtavat kirjallisuus-, minuus- ja historiakäsitykset ovat jatkuvasti suuntauksen harjoittajien hampaissa.

Historian jo usein unohtuneiden nyanssien merkityksen ohella myös nykyisyyden velka myönnetään. Kiinnostuksemme menneisyyttä kohtaan kumpuaa nykyhetken asetelmista. Ja samalla kirjallisen kaanonin asema tunnustetaan - meille se on puhuttelevaa, koska pidämme sitä puhuttelevana - mutta sitä pyritään lähestymään tuoreesta näkökulmasta. Vanhat teokset pyritään näkemään uudella tapaa kiinnostavina ja ajankohtaisina nimenomaan nykyhetkelle tyypillisten kysymysten, kuten sekä varhais- että myöhäismodernille tyypillisten nopeiden yhteiskunnallisten muutosten näkökulmasta.

Usein menneisyyden valittuja kehityskulkuja luetaan rinnan nykyajan vastaavien rinnalla, jotta ymmärrys kummastakin syvenisi. Pyrkimyksenä ei kuitenkaan ole vetää suoria yhtäläisyysmerkkejä ajallisesti ja kulttuurisesti etäisten aikakausien välillä, vaan vain osoittaa tiettyjä jatkumoita tai (osittaisia) samankaltaisuuksia. Analogisuus ei siis 
toisin sanoen ole niinkään tutkimuskohteiden itsensä kuin tutkimuksentekoon liittyvän hahmotustarpeen ominaisuus. Erityisesti varhais- ja myöhäismoderni ovat sellaisia toistuvan tutkimuksellisen kiinnostuksen kohteita, joissa nähdään paljon kiehtovia samankaltaisuuksia. Monet niistä kehityskuluista, jotka vasta hakivat muotoaan uuden ajan alussa, ovat nyt purkautumassa - kuten vaikkapa ajatus omalakisesta yksilöllisyydestä, tai valtion (state) keskeisestä roolista politiikassa. Niinpä modernin "varmuudet", murtumattomiksi nähdyt totuudet ovat erityisen alttiita paljastamaan konstruktioluonteensa nimenomaan silloin, kun niitä aletaan vasta muodostaa - tai kun ne ovat jälki- tai myöhäismodernissa jo hajoamassa.

\section{Kulttuuripoetiikan suosiota selittäviä tekijöitä ja sen kritiikkiä}

Greenblattin ja ylipäätään koko tutkimussuuntauksen jatkuvaa suosiota selittävät paljon sen edellä mainittu vetävä kirjoitustyyli, tietty anarkistinen ja eksistentialistinen pohjavire sekä lukijan eteen leväytetyt laajat näköalat. Kaiken ytimessä on kyky pukea menneisyys sellaiseen muotoon, joka saa lukijan arvioimaan tuttua ja tulkinnoiltaan luutunutta (angloamerikkalaista) kaanonia uudesta, kyseenalaistavasta ja omakohtaisestakin perspektiivistä. Lukija ikään kuin upotetaan korvia myöten kiehtovaan menneisyyteen, vieläpä sellaiseen menneisyyteen, joka näyttäytyy samalla kertaa sekä oudon tuttuna että jollakin määrittelemättömällä tavalla entistäkin vieraampana - etäännytettynä ja silti joiltakin osin hämmästyttävästi nykyajan kaltaisena. Tämä on paljolti kieli poskessa tuotetun, omalaatuisen esitystavan ansiota.

Vetävään kirjoitustyyliin kuuluu myös se jo edellä kuvattu piirre, että kirjallisuuden vaikutuksia tarkastellaan hyvin laaja-alaisesti. Menneisyyttä lähestytään aidosti kiinnostuneena ja mahdollisimman tuoreista tai muuten poikkeuksellisista näkökulmista. Suuntaus kartoittaa hyvin laajasti kirjallisuuden ja historian rajapinnassa ilmeneviä inhimillisiä, kulttuurisia ja eettisiä kysymyksiä. Kulttuuripoetiikan vapaamielinen, kokeileva eetos pohjautuu edelleen myös liikkeen syntysijojen kalifornialaiseen henkiseen ilmapiiriin.Tutkijajoukon monikulttuurisuus sekä sosiaalinen ja (ainakin ennen myös) akateeminen muutoshalukkuus heijastuvat usein tutkimusasetelmiin tavalla tai toisella.

Koska kulttuuripoeettisesta tutkimuksenteon traditiosta on muotoutunut poikkeuksellisen salliva, moniaineksinen ja avoin myös tutkijan subjektiivisille mielleyhtymille, tavoittaa se helposti myös laajemman yleisön. Lähestymistavalla on pistämätön kyky ylittää akateemisten kysymystenasettelujen rajattu ja usein valitettavan abstrakti leikkikenttä. Nimenomaan tässä suhteessa kulttuuripoetiikka palveleekin hyvin suomalaisillekin yliopistoille laissa määrättyä kolmatta tehtävää eli yhteiskunnallista vaikuttavuutta: se osallistuu ja saa osallistumaan suuren lukijakuntansa, poleemisuutensa, näkyvyytensä ja erityisen ajankohtaisten yhteiskunnallisten teemojensa kautta. 
Kuten mitä tahansa menestynyttä tutkimussuuntausta, kulttuuripoetiikkaa ja uushistorismia on arvosteltu rankasti. Esimerkiksi Harold Bloomin mielestä lähestymistavan edustajat, tasapainoillessaan teoreettisten muotivirtausten, kirjallisuuden ja historian välillä, eivät onnistu olemaan sen enempää oikeita "historisteja" kuin aidosti "uusiakaan" - saati kertomaan mitän̈n olennaista kirjallisuudesta itsestään (ks. esim. Weiss 1991, 202). Suuntausta on muutenkin kritisoitu kirjallisuuden tarkastelun summittaisuudesta. Koska se moniaineksisena viittaa yhtä aikaa useampaan suuntaan, muun muassa kirjallisuushistoriaan, historiaan, antropologiaan, psykologiaan, ideologiaan, perinteiseen kulttuurihistoriaan ja toisaalta arjen mikrohistoriallisiin sosiokulttuurisiin käytänteisiin, saattaa yksittäisen kirjallisen teoksen tarkastelusta tulla käytännössä ohut ja hajanainen. Tyypillinen on myös syytös liiallisesta eklektisyydestä. Fiktiivisiä tekstejä luetaan sellaisten (paljolti ei-fiktiivisten) rinnakkaistekstien ohella ja kautta, joiden valikoituminen osaksi kirjallisuustieteellistä analyysia vaikuttaa äkkiseltään sattumanvaraiselta.

Lähestymistapa ei olekaan mainituista synneistä täysin vapaa, mutta kuvatut ongelmat ovat pikemminkin käytännön toteutukseen kuin tutkimuksellisiin perusasetelmiin liittyviä. Itse asiassa parhaat kulttuuripoeettiset tutkimukset ovat rakenteeltaan nimenomaan tasapainoisia ja käytännön valinnoiltaan perusteltuja. Juuri tähän perustuvat niiden jatkuva viehätys ja klassikkoasema. Usein hajanaisuutta korostava kritiikki juontuukin siitä, ettei ole ymmärretty osa-analyysien tai historiallisen taustoituksen merkitystä valitun tutkimuksen kokonaisargumentin kannalta - tai siihen, että halutaan kyseenalaistaa historiantutkimuksen merkitys kirjallisuushistorialle ylipäätään.

Kulttuuripoetiikkaa syytetään myös siitä, että se hylkää vakavan kirjallisuushistoriallisen keskustelun ajaessaan esimerkiksi poliittisen korrektiuden agendaa. Räikeimmillään näin onkin. Toisaalta juuri avoin kantaaottavuus, rohkeiden nykypäivään kurkottavien analogioiden luominen, on yksi niistä keinoista, joilla lukijaa herätellään tarkastelemaan menneisyyttä ja menneisyyden fiktiota tuoreesti. Leikittely historiallisilla analogioilla kuuluu kiinteästi hermeneuttisesta menetelmästä ja postmodernista historiankäsityksestä ponnistavan lähestymistavan luonteeseen. Tämä on tietenkin taitolaji, ja siten altis ajoittaiselle epäonnistumiselle.

Vakavampaa kritiikkiä kohdistuu siihen, että kulttuuripoeetikot eivät aina yllä ammattimaisten historiantutkijoiden tasolle. Esimerkiksi Greenblattin The Swerve syyllistyy tähän kuvatessaan keskiaikaa karikatyyrinomaisesti - vastakohtana oivaltavasti kuvatulle renessanssille, joka onkin ympäristönä kirjoittajan ominta alaa. Varhaista uutta aikaa ja sen henkistä ilmapiiriä kuvataan teoksessa hyvin oivaltavasti ja syvällisesti, suorastaan nerokkaasti. Jotta tämä jälkimmäinen kuva saataisiin kirkkaaksi, turvautuu Greenblatt hyvin jyrkkiin tutkimuksellisiin ja retorisiin valintoihin. 
Kun halutaan sisällyttää kirjallisuushistorialliseen tutkimukseen täysimittaisesti sekä kirjallisuus että historia, ajaudutaan toisinaan alueille, joissa tutkija ei ole omimmillaan. Tutkimuksenteon nälkä saattaa osoittautua omia eväitä suuremmaksi - toki pääsääntöisesti sentään toisin. Menneisyys, menneisyyden tekstit avautuvat kulttuuripoetiikassa uudella, stimuloivalla tavalla. Pahimmillaan lähestymistapa kärjistää, mutta samalla se onnistuu myös paljastamaan jotakin olennaista ja tuoretta. Kulttuuripoetiikka ei kumarra perinteitä eikä aina edes hyviä tutkimustapoja. Radikaali tutkimuseetos onkin hyvä pitää mielessä ostettaessa tätä vetäviin kääreisiin pakattua, värikästä, avoimesti yleisöä kosiskelevaa ja vaikuttavan virtaviivaista tuotetta.

\section{Lähteet}

Greenblatt, Stephen 1984 (1980). Renaissance Self-Fashioning. From More to Shakespeare. Chicago: Chicago University Press.

Greenblatt, Stephen 2011. The Swerve. How the World Became Modern. New York: W. W. Norton \& Company.

Kallionsivu, Mikko 2013. Saiturin kuolema. Kuoleman kulttuuripoetiikkaa angloamerikkalaisessa fiktiossa myöhäiskeskiajalta nykypäivään. Acta Electronica Universitatis Tamperensis 1353. Tampere: Tampere University Press. http://urn.fi/URN:ISBN:978-951-44-9265-5 (30.5.2014).

Weiss, Antonio 1991. Harold Bloom: The Art of Criticism I [Bloomin haastattelu]. Paris Review $118,178-232$. 